\title{
A study on tracking of textile products used in hotel businesses
}

\author{
Zümrüt Bahadır Ünal ${ }^{1}$, Esra Dirgar ${ }^{2}$, Eda Acar ${ }^{3}$, Okşan Oral $^{4}$
}

\begin{abstract}
Because Radio Frequency Identification Technology (RFID) is an efficient system which is easily applicable nowadays, it has wide range of use and this use is increasing day by day. Hotels have become spaces that are visited by the people for various purposes such as relaxing, having holiday, enjoying the time and carrying out some organizations as well as accommodation. Hotels have different units in order to meet the varying requirements of the clients. This variety creates demand for other sectors and has considerable effect on the countries' economy. Hotels that do not make any concessions from their qualities in compelling conditions of competition and wish to keep the bar high are faced with various problems during the process. In this study, a questionnaire was arranged as to textile products used in hotels, the problems experienced concerning product tracking were investigated and the results were assessed in SPSS program.
\end{abstract}

Keywords: Textile and apparel sector, Hotel business, Hotel textiles, RFID

To cite this article: Bahadır Ünal, Z., Dirgar, E., Acar, E., Oral, O. (2017). A study on tracking of textile products used in hotel businesses. Journal of Tourism Theory and Research, 3(1), 9-15. DOI: 10.24288/jttr.279175

\footnotetext{
${ }^{1}$ Corresponding Author, Ege University, Faculty of Enigneering, Textile Engineering Department, İzmir, Turkey, zumrut.bahadir.unal@ege.edu.tr

${ }^{2}$ Ege University, Faculty of Enigneering, Textile Engineering Department, İzmir, Turkey

${ }^{3}$ Ege University, Faculty of Enigneering, Textile Engineering Department, İzmir, Turkey

${ }^{4}$ Ege Üniversitesi, Bergama Vocational High School, İzmir, Turkey
} 


\section{Introduction}

Radio Frequency Identification Technology (RFID) is an automatic identification system that allows the products to be identified by using radio waves. It consists of several components such as tags, tag readers, edge servers, middleware and application software (Nayak et al., 2007). This technology came to be used during the 1960s even though it first appeared aftermath of the 1st World War. Thanks to this technology, the product mobility can be monitored fast and in a reliable way, at which time the failures in the activities can be prevented. Thus, it became possible for the conducted facilities to be carried out in a more efficient way (Özulucan and Özdemir, 2009). These labels can collect large amount of information, they can be read and written faultlessly and fasten masse, they can be used in different environmental conditions and they can provide data communication from long distances thanks to readers (Üstündağ and Korkmaz, 2006).

Smart tags have been used by many sectors in various fields such as retail business, automative, textile, health, food business, and defense (Üstündağ, 2008). It was mainly used by the military in the beginning. The progress in microchip design, antenna technology and radio spread spectrum pushed it into various applications like supply chain management, retail, automatic toll collection by tunnel companies, animal tracking, ski lift access, tracking library books, theft prevention, vehicle immobilizer systems, railway rolling stock identification, movement tracking, security, healthcare, printing, textiles and clothing (Nayak et al., 2015).

\section{The use of RFID in tourism sector}

At a fast-growing position, tourism sector makes use of information technologies in various fields in order to ensure customer satisfaction, productivity and quality improvement in a competitive environment. RFID technology allows hospitality organizations to collect real-time data about their customers that helps them to customize their services. Some of the RFID applications in the hospitality industry include cashless payment systems, building intelligence systems, customer loyalty systems, luggage tracking, inventory tracking and asset management, RFID electronic locking systems, and RFID meeting technology (Hassannia, 2014).

Significant results were obtained thanks to the use of smart tags in hotels as tracking system. Upon the increase in theft of towel by 5 to 20 percent in the US, washable microchips have come to be attached to the textile products such as towels, bathrobes and sheets. A Miami-based company has developed a system against theft of towel in the face of high cotton prices thanks to chips with tracking properties by means of radio frequency that it produced. This investment yielded return of some 15.000 dollars (Sabah, 2011). In another hotel in Miami where the similar policies were implemented, the number of towels stolen decreased from 4000 to 750 , and the replacement costs reduced to the amount of 16.000 dollars (Schneier on Security, 2011).

A Buenos Aires luxury hotel is using RFID to make sure employees always have a clean, crisp uniform ready when they show up at work. RFID technology is being utilized to track and manage the lifecycle of its employees' uniforms. The occasional short supply of clean uniforms was a big issue for the hotel, because many uniforms were imported and, therefore, could not be quickly replaced. A small RFID tag was attached to every jacket, shirt, pair of pants and other article of clothing in its uniform inventory (Falken and Secure Networks).

\subsection{Situation of the tourism sector in Turkey and the use of RFID}

Tourism is the biggest sector after agriculture and industry particularly in the developed countries, and as is the case around the World, it maintains its feature of being an industry continually growing in Turkey as well. While the number of visitors who came to Turkey for touristic purposes was 4.4 millions in the 1990s, when the tourism industry began, it exceeded the number of 30 millions in 2000s and it attained an important place in the World market. Presently, of the countries the tourists prefer as holiday destination, Turkey has become the 6th in the World ranking (TÜROFED, 2015).

Turkish tourism was able to reach positive growth figures in 2013 by getting out of regional instabilities. According to the targets revealed in the 10th development plan, which covers the years of 2014- 
2018 and which was prepared by the Ministry of Development, 42 million tourists were aimed and the revenues obtained from tourism were expected to be 45 billion dollars (TÜROFED, 2015).

Increasing the productivity and quality in a competitive environment that arise depending on the growth in this fast-growing sector is very important in terms of customer satisfaction. In this context, it is observed that the use of information technologies is quite common. These technologies, in tourism sector, are used in obtaining the data such as quickly reaching the information of location where the staff or equipment is, as tracking the customers' participation in the activities, as detecting children's location within the hotel when needed, as easily reaching the goods in case of theft and loss, in which hall the participants are present and how long they remain there and which sessions they attend in the congress organized (WIPELOT,2016). The investment made in this field ensures the increase of customer satisfaction by preventing its lost when it acquires functionality, ensuring labour force, easing business processes, reducing the costs and preventing time loss.

Hotels, which are situated in lively places in terms of tourism such as Istanbul and Antalya in Turkey, have established a platform that can be traced textile materials by using various tracking systems. The desired data can be reached by installing the products the necessary materials such as chip or RFID label in the industrial laundries they have agreement with. The firms' active inventories, their lost products, the products' history of mobility, and current wash ages can be recorded by tracing the product mobilities. Radio Frequency Textile Tracing (RFTT) system, developed by PAK Laundry, was first implemented in Divan Hotel, and textile exchange between the customer and laundry was transferred to digital environment. Thanks to the system, handover got easy, and delivery and the quality control processes were conducted quite fast and faultlessly (Turizm Dünyası, 2016).

The smart tags installed to the textile products in the hotels can tolerate about 250 washings and 40 bar pressure. In the laundries, there are generally RFID cabins than can count the products with this tag. The products scanned by these cabins can be counted in a way like 300 pieces $/ \mathrm{sec}$. without requiring any extra staff (Turizm Dünyas1, 2016). This system is of great importance in terms of both preventing labor force and taking under control of the textile products.

\subsection{Hotel textiles production and trade in Turkey}

Today, lodging industry has quite developed for the reasons such as the increase of people's welfare level in the course of years, and as the need for accommodation depending on the increase in business trips and holidays. Therefore, the production of textile materials which are commonly used in the hotels showed increase. These products groups that are commonly used in the hotels are the products whose production are made in the home textile sector which is the sub-sector of textile and apparel industries. The data pertaining to home textile are predicated while export and import figures are being analyzed.

The major cities where production is concentrated in Turkey, which has become one of the providers of leading home textile in the World, are Bursa, Denizli, Istanbul, Izmir and Usak. Bursa is distinguished particularly with its production of towel, tulle and sheet; Denizli with its production of towel and sheet; Usak with production of blanket and Istanbul with tulle and curtain. The figure pertaining to home textile exports between 2005 and 2014 in Turkey has been provided below (TETSİAD, 2015).

Figure 1. Home textile export values between the years of 2005 and 2014

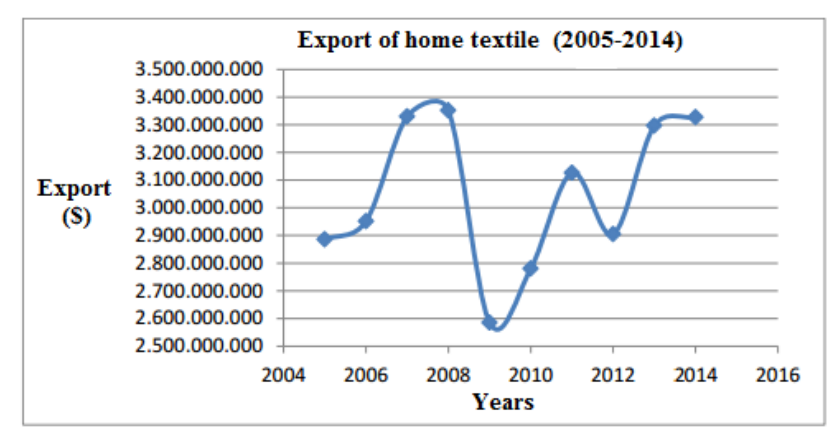

Turkey is the fourth biggest country of the World in the exportation of home textile productions. Home textile sector is one of the sectors that has the most foreign trade surplus in terms of the use of domestic raw materials and of its high employment potential.

When, on the other hand, the export figures are analyzed on the basis of product, it is observed that the highest export in total home textile exportation is achieved in "towel and robe"( TETSİAD, 2015). 
Hotel textile used in many fields in the hotels from hygiene to decoration and from frequency of use to the number of used products is included among the product items. The companies that have created different collections in hotel textile state that hotels purchase 100-150 kinds of goods in textile group in their inaugurations. With its rich product range, hotel textile is included in the product groups which are frequently renewed because of their intensive use and to which new sorts of products are added (Hometextile Dergisi, 2015).

Product groups of hotel textiles being used presently are classified under four main categories in the table below.

Table 1. Product group of hotel textiles

Bed group: $\quad$ Sheet, pillow case, quilt, pillow, undersheet, pique and blanket

Wet area group: Towel, bathrobe and loin cloth

Restaurant group: Table cloth, runner, napkin box and decorative trim

Decoration group: Tulle, curtain and upholstery fabric

This study was carried out with the aim of determining whether there is a need for RFID tags as to counting, inventory and protection of textile products used in hotels. In the study, the textile products used in hotels were determined on the basis of amount and variety, and then data were obtained as to which product groups losses were observed in particular and what kind of practices were implemented for tracing these products. In this context, the survey questions prepared were applied in 137 hotels, and the results were assessed with SPSS program. It is thought that the results obtained will be of use to hotelkeepers and entrepreneurs.

\section{Methodology}

By the year 2015, there are 3131 hotels affiliated to the Ministry of Culture and Tourism (TURSAB, 2015). In accordance with the field study based on the survey, between July 2014 - March 2015 it has been worked totally with 137 hotels which are classified as 2,3,4 and 5 star hotels, including boutique and apart hotels in accordance with Tourism Promotion Law and located in Aegean, Mediterranean, Black Sea, Marmara and Central Anatolia regions.

In the course of the study, interviews were arranged with the 4 and 5 stars hotels at first because they are in need much more of hotel textile products, and in these interviews, face-to-face interviews were conducted with the people in charge of the purchase departments of these hotels. The questionnaire was sent via e-mail to the hotels to which the researchers could not go. The distribution of hotels taking part in the study is shown in Figure 2 below. According to the data, four starts hotels ranked first by $35 \%$, while five stars ranked the second by $25,5 \%$.

Figure 2. Percentage of hotels taking part in the study

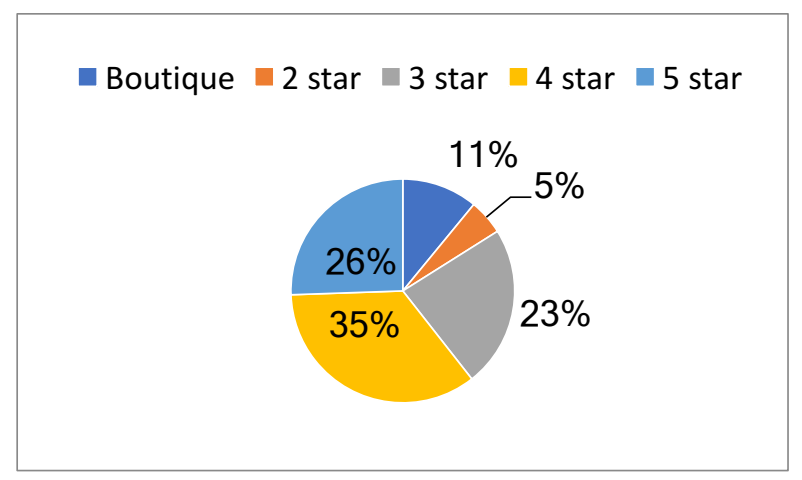

Primarily, general information was obtained about the hotels thanks to the questionnaire forms prepared, textile materials within the hotels and the amounts purchased every year were determined, and then the criteria the hotels considered in purchasing the materials were prioritized.

In assessing the data of the survey, SPSS 18 statistics software was used and the survey results were analyzed. First, descriptive statistics were obtained and then the relations among the determined criteria were analyzed. Finally, it was investigated whether the hotels took precautions as regards the tracing of textile materials, which is the main purpose of the present study, and which methods were applied for the precautions taken. 


\section{Findings}

Average, maximum and minimum values of the textile products belonging to the hotels to which the questionnaire applied were shown in Table 2 . According to the data, the questionnaire was applied to the hotels the bed amount of which is 2500 maximum, 14 beds minimum, and the average number of bed was 293.

Table 2. Average, maximum and minimum values of textile products belonging to the hotels

\begin{tabular}{|l|c|c|c|}
\hline & Average & Maximum & Minimum \\
\hline Bed amount & 293 & 2500 & 14 \\
Face towel & 418 & 3750 & 10 \\
Foot towel & 336 & 3750 & 10 \\
Bath towel & 420 & 3750 & 10 \\
Beach towel & 909 & 4000 & 30 \\
Bathrobe & 402 & 3000 & 10 \\
Blanket & 138 & 1450 & 10 \\
Pique & 290 & 5000 & 10 \\
Sheet & 451 & 5000 & 10 \\
Pillow case & 608 & 5000 & 10 \\
\hline
\end{tabular}

The number of the textile products annually purchased by the hotels where the survey was carried out is 3120 . It is the beach towel that has the biggest share among the textile products the hotels purchase in a year. Then comes the pillow case. It was seen that blanket has the lowest share among the products purchased annually. $62,8 \%$ of the product groups is white and $37,2 \%$ of them is other colours.

$56,2 \%$ of the textile products bear ornaments or hotel's logo. This situation is a tempting point in terms of hotel clients' taking the textile products with them.

In Table 3, the criteria which the hotels take into account when they purchase hotel textiles were provided. It was observed that $42,3 \%$ of the hotels consider the material and production quality to be in the first place, while $21,9 \%$ of them regard the prices in the first place.

According to the results obtained from the conducted study, it became apparent that some losses have been experienced in the textile products used in 112 hotels, that is, in $81 \%$ of them.
Table 3. Distribution of criteria related to purchasing hotel textiles

\begin{tabular}{|l|c|c|}
\hline & Frequency & Percent \\
\hline Price & 30 & 21,9 \\
Visuality & 4 & 2,9 \\
Fashion of the moment & 1 & 0,7 \\
Material and production quality & 58 & 42,3 \\
Customer convenience & 6 & 4,4 \\
Suitability to the hotel concept & 13 & 9,5 \\
All & 2 & 1,5 \\
Total & 137 & 100,0 \\
\hline
\end{tabular}

It was determined that within 137 hotels where the study was carried out, the amount of products lost in a year is 3500 maximum and the average annual loss is 293. However, it was determined that in some hotels, any case of product loss was not experienced owing to the precautions taken such as controls in check-outs or barcode systems. In the below graph, the minimum and maximum numbers of the lost products were given according to the hotel type.

Figure 3. Annual lost product amount according to the hotel type

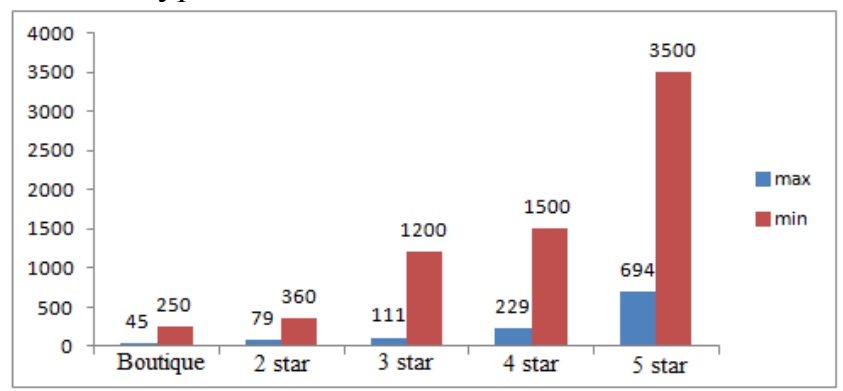

When examining the class distribution of the losses observed in the textile products in hotels, it is seen that of all the product groups, it is towels with $65,7 \%$ that customers take with them while leaving the hotels. The cost of hand towels or napkin boxes, the most used and lost products, is $5 \mathrm{TL}$ per each. According to the survey results, a hotel that experience 3.500 pieces of lost from the above products has to burden additionally 17.500 TL financial cost, which is a significant amount.

The applications of hotels in tracing their products are given in the below graph, and only two hotels to which the survey was applied use barcode system. 
Figure 4. Applications of hotels in tracking their products

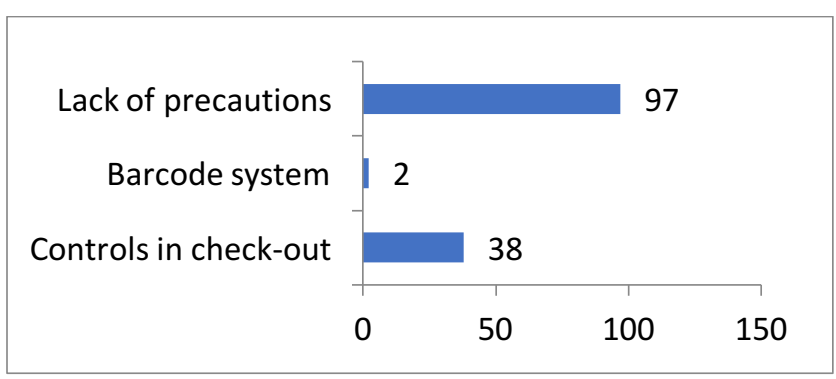

Because types of hotels included in the study are different from one another, values were calculated proportionately in order to be able to compare and comment on the relationships among them. The number of lost textile products was proportioned to the number purchased, and then the rate of lost products was obtained. Afterwards, normalisation was made. Since two-stars, apart and boutique hotels are less in number, they were gathered under the group of "other".

Table 4. Rate of lost product according to hotels' number of stars

\begin{tabular}{|ccc|}
\hline $\begin{array}{c}\text { Number of } \\
\text { stars }\end{array}$ & N & Mean \\
\hline 3 & 32 & $9,76 \%$ \\
4 & 48 & $11,79 \%$ \\
5 & 35 & $10,25 \%$ \\
Other & 22 & $8,16 \%$ \\
Total & 137 & $10,34 \%$ \\
\hline
\end{tabular}

According to Kruskal-Wallis Test analysis, statistically no significant difference was found between the hotels' number of stars and rate of lost product variable $(p=0,230)$. From this point of view, it was concluded that customers take textile products with them regardless of type of hotels.

According to Kruskal-Wallis Test analysis, no significant difference was found between the variables of the lost products rate and their being colorful or white, or their bearing hotel's logo, name or ornament $(\mathrm{p}=0,636)$. Customers continue to exhibit the same course of conduct irrespective of color or design.

According to Kruskal-Wallis Test results, there is no significant relationship between the rate of lost product and barcode system, one of the types of precautions that hotel developed for tracing products, and control or taking precaution while check-out $(\mathrm{p}=0,408)$. This situation can be thought of as the main reason for the result obtained, because only two of the hotels participating in the survey use barcode system.

\section{Conclusion and general evaluation}

Within the scope of study, the survey was applied to 137 hotels. According to the results of the survey, $81 \%$ of the hotels taking part in the survey are experiencing product lost. Of the textile products that are lost, towel has become the top with $65,7 \% .97$ hotel managements do not use any tracing system for tracing the products, while 2 hotel managements use only barcode system. Statistically, no significant difference was observed between the rate of lost products and number of stars the hotels have, colours and designs of products, and their bearing logos and the application developed for tracing products. It was concluded that customers take the products with them for various reasons regardless of the types of hotels.

The number of lost products increases more when the clothes the staff wear are added to the textile products the hotels purchased. The inventory, cleaning and protection of these textile products and their replacements with the new ones when they are worn off or when they decrease take quite a lot of time. Therefore, it has become compulsory for particularly the large managements to use textile products to which the RFID tags are attached.

When interviews are made with the hotels operating in our country, there are few hotel managements that use RFID system directly within their structure and that assess the data they obtain, while a number of hotels located in vicinities of Antalya, Istanbul and Muğla have just planned to put this system into practice yet.

On the other hand, when the interviews are made with the hotels that use this system, the hotels in question do not make the processes such as the supply of textile products and/or the chips' being inserted to materials, and they leave such jobs to industrial laundries; in addition, they don't follow the data periodically. While the data obtained thanks to the use of external source are commonly used in other sectors, they are quite a new field for our country in hotel sector. 
There are also disadvantages in using RFID tags in the service sector. Managements hesitate as to warning the customers particularly in the event of noticing the decreased product. The fact that hotels state that they make use of information technologies such as RFID in their advertisements may be deterrent in terms of customers.

In the prospective studies, the data which the hotel managements that have framed the tracing system in their structure obtained can be assessed in terms of cost and statistical evaluation can be made. Separately, the effect of tracing systems on the parameters such as rate and flexibility that directly affect the process and that have effect on customer satisfaction and competitiveness can be analyzed. On the other hand, the analysis of the respect that customers take the products with them can be thought of as another subject of study.

\section{References}

Havlu Hırsızlığına Çipli Çözüm. (2011, 20 Nisan). Sabah, http://www.sabah.com.tr/turizm/2011/04/20/havluhirzisligina-cipli-cozum

Hassannia, R. (2014). The Multipurpose Application of Radio Frequency Identification (RFID) in The Tourism Industry: On a Requirement Analysis For Employing RFID Technology in the Hotel Sector. Eastern Mediterranean University, Doctoral dissertation.

Hometextile Dergisi, Otel Tekstili. (2015). http://issuu.com/tetsiadevtekstili/docs/hometexti le_mart_2015

İstanbul Laundry, RFID Sistemi ile Yıkama İstatistiklerini Raporluyor. (2016). Turizm Dünyasl, http://www.turizmdunyasi.com.tr/arsiv/yazi/137istanbul-laundry-rfid-sistemi-ileyikama-istatistikleriniraporluyor\#sthash.SCeEGadc.dpuf.

Nayak, R., Chatterjee, K. N., Khurana G. K., Khandual, A. (2007). RFID: Tagging the new ERA. Man-Made Textiles in India, 50(5), 174-177.
Nayak, R., Singh, A., Padhye, R., Wang, L. (2015). RFID in textile and clothing manufacturing: technology and challenges. Fashion and Textiles, 2(1), 1-16.

Özulucan, A. and Özdemir, F. S. (2009). Nesneleri Radyo Frekansları ile Tanımlama Sisteminin Etkinlik ve Maliyetler Üzerindeki Etkisi. World Of Accounting Science, 11(4), 21-56.

Radyo Frekansl1 Tekstil Takip Sistemi. (2016). Turizm Dünyasl, http://turizm dünyası.com.tr/arsiv/yazi/radyofrekansly-tekstil-takip-sistemi

RFID Tags Protecting Hotel Towels. (2011). Schneier on Security, https://www.schneier.com/blog/archives/2011/05/rfid_t ags prote.html

RFID for Hotels. Falken and Secure Networks http://www.falkensecurenetworks.com/PDFs/0830_RFI D_for_Hotels.pdf

TETSİAD, Ev Tekstili Dış Tícaret Raporu. (2015). http://www.tetsiad.org/files/download s/bilgi_bankasi/ulke_raporlari/Dis\%20Ticaret\%20Rapo $\mathrm{ru} \% 20$ Subat $\% 202015$.pdf

Turizm Sektöründe Kablosuz Çözümler. (2016). WIPELOT Kablosuz Elektronik Çözümler. http://www.wipelot.com/Cozumler/Turizm- RFIDCozumleri

TURSAB, Turistik Tesis ve İşletmeler. (2015). http://www.tursab.org.tr/tr/turizm verileri/istatistikler

TÜROFED, Turizm Raporu. (2015). http://www.turofed.org/_files/_pdf/turizm_raporu_15_2 pdf .

TÜROFED, Turizm $\quad$ Raporu. (2015). http://www.turofed.org.tr/__ files/_pdf/turizm _raporu_sayi_6.pdf

Üstündağ, A., Korkmaz, E. (2006). Radyo Frekanslı Tanıma Teknolojisinin (RFID) Endüstriyel Kontrol Sistemlerine Entegrasyonu. 6. Ulusal Üretim Araștırmalart Sетровуити (UAS), 501-510.

Üstündağ, A. (2008). Radyo Frekanslı Tanıma (RFID) Teknolojisinin Tedarik Zinciri Üzerindeki Etkileri. Istanbul Technical University, Doctoral dissertation. 